\title{
Siltstone Geochemical Compositions: Applications for Event Size and Correlation
}

\author{
Kannipa Motanated1*, Michael M. Tice ${ }^{2}$ \\ ${ }^{1}$ The Department of Geological Sciences, Chiang Mai University, Chiang Mai, Thailand \\ ${ }^{2}$ The Department of Geology and Geophysics, Texas A\&M University, Texas, USA \\ Email: "kannipa.motanated@cmu.ac.th
}

Received 31 December 2015; accepted 26 February 2016; published 29 February 2016

Copyright (C) 2016 by authors and Scientific Research Publishing Inc.

This work is licensed under the Creative Commons Attribution International License (CC BY). http://creativecommons.org/licenses/by/4.0/

(c) (i) Open Access

\section{Abstract}

Thinly laminated siltstone and sandy siltstone are major components of the Upper Permian Brushy Canyon Formation, west Texas and south New Mexico. These rocks have been variously interpreted as the deposits of low-density turbidity currents or as windblown sediment deposited over water. Nevertheless, all models agreed that this lithology was deposited without subsequent reworking by bottom currents or burrowing organisms. These siltstones, thus, are ideal test units for quantitatively estimating hydraulic properties of the flows that formed them. In particular, the $\mathrm{Zr}$ /Ti ratio was tested as a geochemical proxy for flow size and transport distance. In situ geochemical abundance and grain size of particles with contrasting susceptibility to erosion- $\mathrm{Zr}$ - and Ti-rich particles-were mapped and measured by X-ray fluorescence analytical microscopy, $\mu$ XRF. Lamination thickness was measured from Fe fluorescence intensity, which increased sharply at the top of each layer. Within the same sample, zircon grains were systematically finer than rutilated quartz grains. $\mathrm{Zr} / \mathrm{Ti}$ fluorescence ratio positively correlated with lamination thickness, not particle sizes. In other words, $\mathrm{Zr}$ / $\mathrm{Ti}$ fluorescence ratio fluctuations resulted from variations in mineral abundance. Therefore, variations of $\mathrm{Zr}$ / Ti fluorescence ratio in these siltstones are likely caused by fluctuations in the intensity of erosional events rather than transport distance. High $\mathrm{Zr} / \mathrm{Ti}$ ratios and thick laminations reflect periods of enhanced erosion. The average wind velocity during typical events was estimated to be at least $150 \mathrm{~km} \cdot \mathrm{hr}^{-1}$, or the equivalent of a Category 1 hurricane. The method used here could be applied to both outcrop and subsurface strata correlation.

\section{Keywords}

Windblown Dust, Laminated Siltstones, Geochemical Mapping, Upper Permian Brushy Canyon Formation

${ }^{*}$ Corresponding author. 


\section{Introduction}

The unit chosen for study is the gray fine to medium grained thinly laminated siltstones and sandy siltstones of the Brushy Canyon Formation in the Delaware Mountain Group located in the Delaware basin, west Texas and south New Mexico. This basin was tectonically created and able to contain about 1000-m-thick deposits [1]. The Brushy Canyon Formation is middle-late Permian deposit that mainly composes of channel-fill massive sandstone and laminated siltstone [1]. Wind-transported but water-laid density currents (eolo-marine) have, previously, been proposed as sediment transportation and depositional models of the siltstones. Reference [2] interpreted that the sedimentary rocks of the Delaware Mountain Group sediments were deposited from dual density flows, where saline density currents deposited sands and less-dense currents deposited detrital silt and organic materials. Light gray laminae was coarser and organic-poor whereas darker gray laminae was finer and organicrich [2]-[4]. Siltstone was deposited from suspension without any influence from the bottom currents because the siltstone was 1) draping as a laterally continuous and uniform blanket, 2) lacking current structures and 3) rich in organic matter, and 4) each lamina was individually graded, increasing in organic content upward [2] [4]. References [5] and [6] concluded that the Delaware Mountain Group was deposited from turbidity currents during a period of low sea level. Thus, abundant sediments were transported into the basin by sediment-gravity flows. High-density turbidity currents generated channel filling sandstones while laminated siltstones were deposited from dilute, low-density turbidity currents [6].

On the other hand, reference [3] proposed an eolo-marine or wind-transported but water-laid model for the deposition of the Delaware Mountain Group because 1) the paucity of clay found in the deposits suggested an eolian origin, 2) fallout of windblown dust could create topographically draping beds of laminated siltstones, and 3) these deposits were similar to Pleistocene paraglacial deposits of the Sahara. In this model, sands were transported by eolian dunes and fine sand, silt, and clay were transported as dust. Deposition of sand wedges at the shelf break during low sea level generated turbidity currents and, consequently, channel filling sand bodies. Fine sand and silt were deposited as hemipelagic laminated siltstones. During the Permian time, the Delaware basin was located in the trade-wind belt of the northern hemisphere [3]. Fine sand, silt, and clay were transported as wind-blown dust [7] by strong trade-wind periods [3]. Compositions of detrital feldspar suggest that the source areas were the Rockies and other uplifts [8]. Sediments in the thinly laminated siltstone samples were, therefore, initially moved by wind.

Although [2]-[6] proposed different models of transportation of the Delaware Mountain Group sediments, their findings unanimously agreed upon the mode of deposition of the thinly laminated siltstones. This lithology topographically draped preexisting layers and was deposited from suspension with little or low disruption or alteration by bottom currents. The rock unit was deposited from suspension in dilute fine-grained turbidity currents, hemipelagites, or both; mineral distribution and lamination were not affected by bottom currents. Particles in these laminated siltstones were, thus, hydraulically equivalent in dilute suspensions. Characteristics of hydraulic conditions at the time of particle erosion, transportation and deposition are preserved in these laminae.

$\mathrm{Zr} / \mathrm{Ti}$ ratios were estimated for individual laminations and compared with lamination thicknesses as well as the abundances and sizes of zircon and rutilated quartz grains. Previous studies suggest that $\mathrm{Zr} / \mathrm{Ti}$ ratios reflect either transport distance (proximity to the source) [9] [10] or the magnitude of the flow that eroded, transported, and deposited the sediment [11]-[13]. Hydraulic characteristics of fluid medium are reflected in these geochemical patterns. Since the laminae are uninterrupted by bottom currents or burrowing organisms, the original conditions of lamination thickness and spatial mineral distributions are preserved. These siltstones are, consequently, an ideal test unit for 1 ) identifying causes of geochemical composition variation which could be applied to strata correlation and 2) estimating the velocity of erosional fluid, event size, in order to better understanding the origin of this rock unit and, ultimately, the basin's evolution as a whole. X-ray fluorescence analytical microscopy (Horiba XGT-7000 X-ray Analytical Microscope), $\mu$ XRF, was used to observe and measure the geochemical compositions of slabbed rock samples. This instrument is able to produce high-intensity X-ray beam of $10 \mu \mathrm{m}$ in diameter [14], allowing in situ and non-destructive measurements of particle size and characterization of elemental spatial distributions.

\section{Method}

Fifteen hand samples of thinly laminated siltstones were collected from three measured sections from the Upper Brushy Canyon Formation, Guadalupe Mountains National Park, west Texas. The measured sections came from 
thinly laminated siltstone outcrops overlying a prominent structureless sandstone bed representing late-stage channel fill in a large channel body exposed on Salt Flat Bench (Figure 1). X-ray fluorescence analytical microscopy (Horiba XGT-7000 X-ray Analytical Microscope), $\mu$ XRF, was used to map elemental distribution in slabbed hand samples. Scans were conducted at $10 \mu \mathrm{m}$ resolution over $5.12 \mathrm{~mm} \times 5.12 \mathrm{~mm}$ scanning areas to detect and characterize individual grains; two to four $10 \mu \mathrm{m}$ resolution scans were conducted from the base to the top of each sample. Zircon and rutile grains were mapped by integrated $\mathrm{Zr}$ and Ti fluorescence intensities. Major and minor axes of these grains were measured as the full width at half maximum fluorescence intensity (background subtracted) measured across grain transects. Grains were selected for measurement by digitally overlaying grids having cell spacing more than twice the diameter of the largest grains and measuring the single grain closest to each node. Since flat or elongate grains have significantly different fall velocities than spherical grains of identical volume, grain shape was quantified by the Riley Sphericity, $\psi_{r}$ [15]. Grains with $\psi_{r}$ less than 0.69 were not included in estimates of fall velocity distributions. Lamination thickness was measured directly
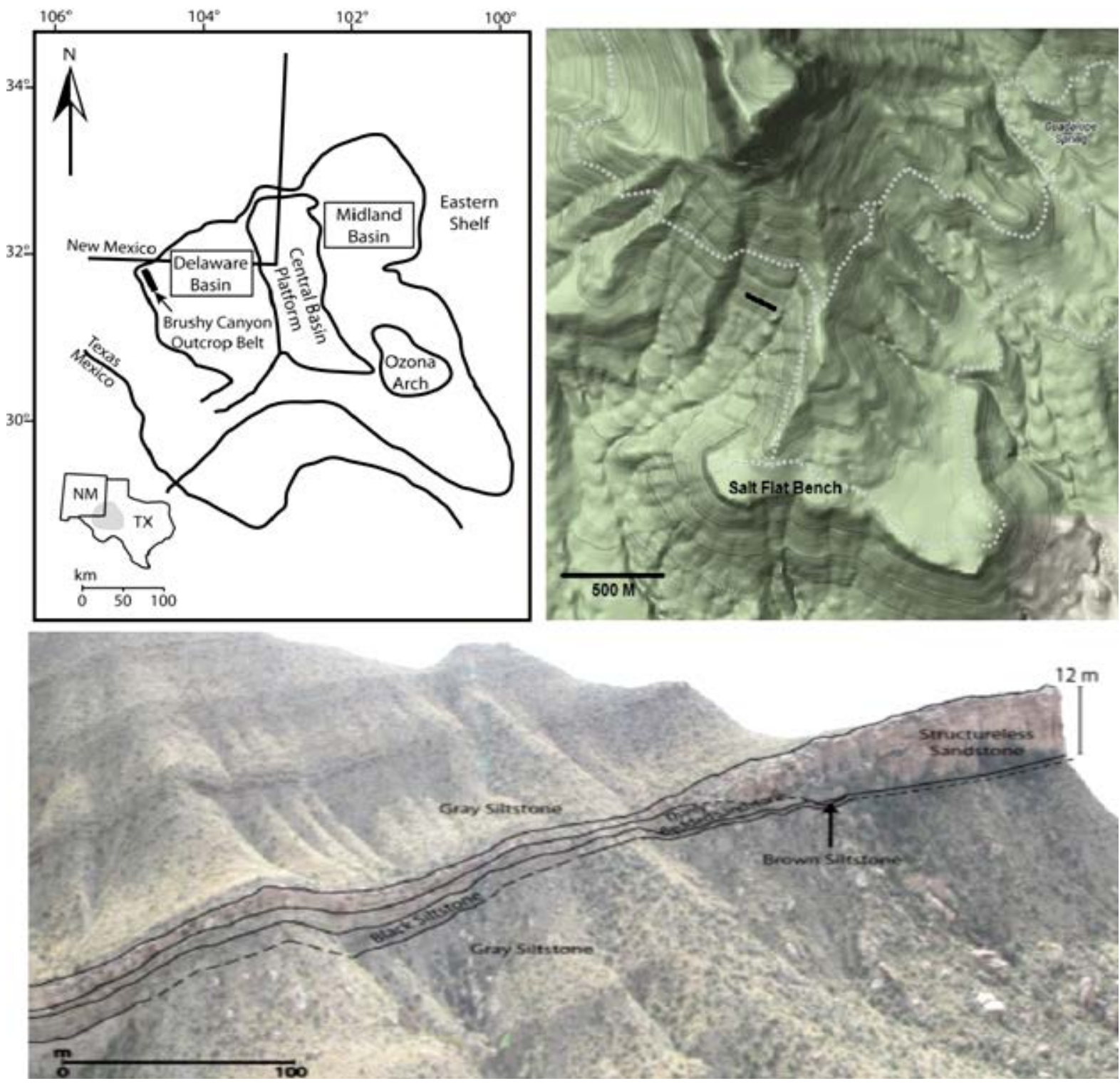

Figure 1. A prominent structureless sandstone bed exposed on Salt Flat Bench (vertically exaggerated outcrop photo to show different deposits). The measured sections came from thinly laminated siltstone outcrops (Gray Siltstone) overlying this late-stage channel filling structureless sandstone. The sampling location's GPS coordinates: N 31.871, W 104.858. Modified from [16]. 
from Fe fluorescence intensity distributions. Dark gray/black laminae are enriched in Fe while light gray laminae are Fe-poor. The distance between adjacent Fe fluorescence intensity peaks is therefore equal to lamination thickness. $\mathrm{Zr} / \mathrm{Ti}$ fluorescence ratio was calculated by dividing the average fluorescence intensity of $\mathrm{Zr}$ by that of $\mathrm{Ti}$ within the same lamination. The relationships between $\mathrm{Zr} / \mathrm{Ti}$ fluorescence ratio and grain size, $\mathrm{Zr} / \mathrm{Ti}$ fluorescence ratio and lamination thickness, and particle size of minerals with relatively high and low susceptibility to erosion were used to infer sources of geochemical variation of these thinly laminated siltstones.

\section{Results}

\subsection{Zircon and Rutilated Quartz Concentrations and Distributions}

Zircon and rutilated quartz grain sizes were log-normally distributed (Figure 2) with sample standard deviation $<0.35 \phi$ (very well-sorted). In every scanning location, rutilated quartz grains were systematically larger than zircon grains (Figure 3). Zircon grains were silt-sized, and rutilated quartz grains were very fine sand-to coarse silt-sized. Additionally, rutilated quartz grain sizes were positively correlated $(r=0.771)$ with those of zircon grains (Figure 3). This correlation is consistent with the hypothesis that they were sorted together during deposition from suspension and that they were hydraulically equivalent at the time of deposition. Consequently, the

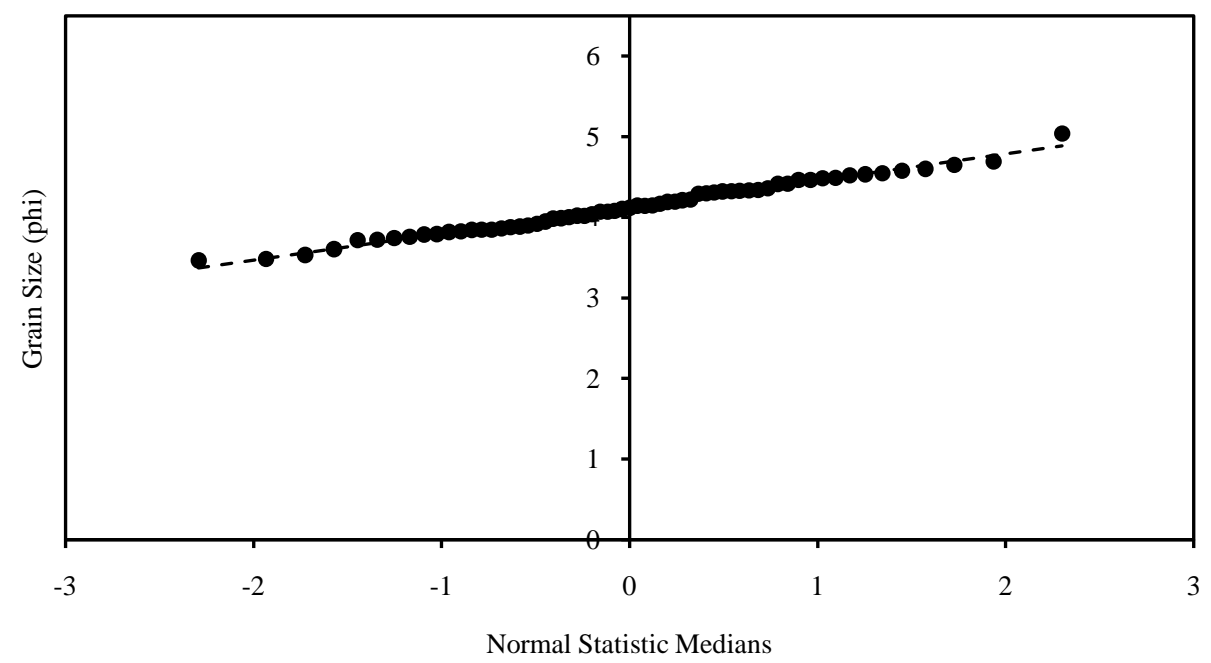

Figure 2. Normal probability plots of rutilated quartz grain sizes from small scans show that these grains are normally distributed $\left(R^{2}=0.988 ; p=10^{-33}\right)$.

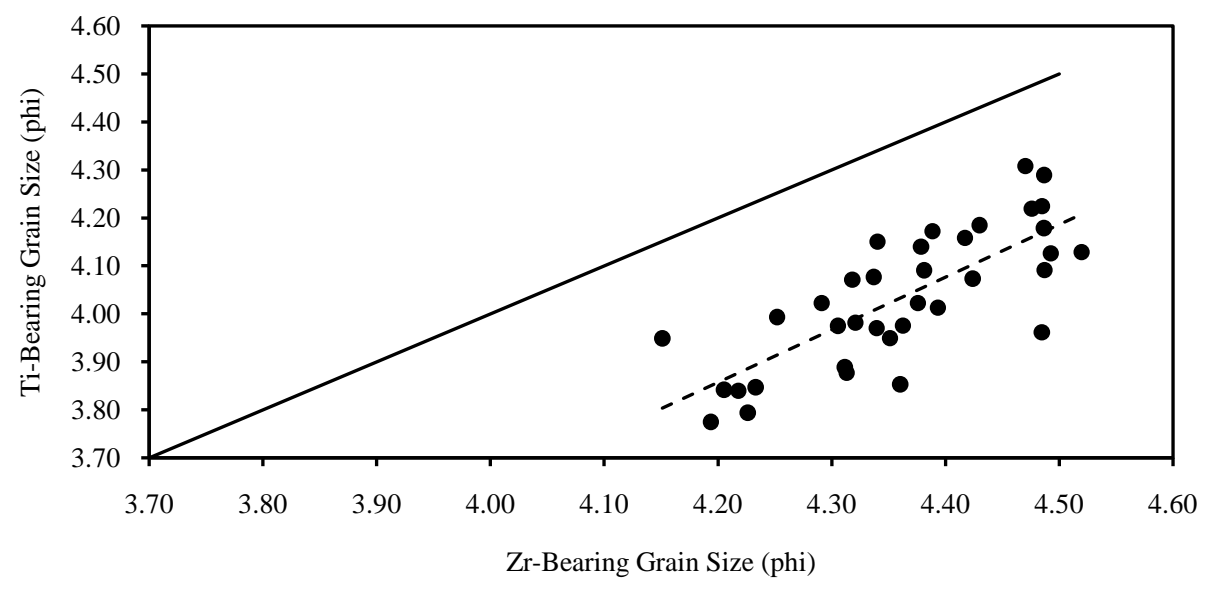

Figure 3. Rutilated quartz grain size (phi) with respect to zircon grain size (phi) from each $10 \mu \mathrm{m}$ resolution scanning location is shown in dots. A line of $1: 1$ grain size ratio is displayed in solid line. Linear regression line (dashed line) has a slope of $1.098 \pm 0.316$ (95\% confidence) and $p$-value of $10^{-8}$. 
average density of rutilated quartz can be estimated by balancing the Stokes settling velocity of rutilated quartz with that of zircon.

$$
\left(\frac{\mathrm{d}_{\mathrm{Zr}}}{\mathrm{d}_{\mathrm{Ti}}}\right)^{2}=\frac{\rho_{\mathrm{Ti}}-\rho}{\rho_{\mathrm{Zr}}-\rho}
$$

The above equation can be rewritten in the following linear form:

$$
\phi_{\mathrm{Ti}}=\phi_{\mathrm{Zr}}+\frac{1}{2} \log _{2}\left(\frac{\rho_{\mathrm{Ti}}-\rho}{\rho_{\mathrm{Zr}}-\rho}\right) .
$$

Here, $d_{\mathrm{Zr}}$ and $d_{\mathrm{Ti}}$ represent zircon and rutilated quartz diameters. $\rho$, $\rho_{\mathrm{Zr}}$, and $\rho_{\mathrm{Ti}}$ are densities of fluid, zircon, and rutilated quartz, respectively. $\phi_{\mathrm{Zr}}$ and $\phi_{\mathrm{Ti}}$ represent zircon and rutilated quartz grain size in phi-scale. The regression line between quartz and zircon grain sizes had a slope of $1.1 \pm 0.3$ (Figure 3 ) but the slope's intercept $\neq$ 0 . Therefore, the densities of these minerals were not equal to each other. These minerals were hydraulically equivalent, and the density of rutilated quartz was calculated by equating the settling velocity of zircon to that of quartz particle. Rutilated quartz grains had an average estimated density of $3.34 \pm 0.05 \mathrm{~g} \cdot \mathrm{cm}^{-3}$ (standard error from 36 measurements), suggesting an average rutile content of $43 \%$ by volume.

There is no significant correlation between $\mathrm{Zr} / \mathrm{Ti}$ fluorescence ratio and either zircon or rutilated quartz grain sizes (Figure 4 and Figure 5). In other words, variations in $\mathrm{Zr} / \mathrm{Ti}$ ratio were not caused by variations in mineral grain size.

\subsection{Lamination Thickness}

Alternating light gray laminae and darker gray/black laminae were horizontal and parallel to each other. Black laminae were enriched in Fe (Figure 6) allowing consistent estimation of lamination thickness from $10 \mu \mathrm{m}$ resolution $\mu$ XRF scans. All samples showed positive correlations (positive $r$-value; Table 1; Figure 7), and nine

Table 1. Linear regression and correlation analysis between lamination thickness and $\mathrm{Zr} / \mathrm{Ti}$ ratio. Lamination thickness and $\mathrm{Zr} / \mathrm{Ti}$ ratio are positively correlated in every sample.

\begin{tabular}{cccc}
\hline Sample & Slope & $P$-Value of The Slope & Correlation $R$-Value \\
\hline $1-3$ & 0.152 & $0.007^{\mathrm{a}}$ & 0.853 \\
$1-4$ & 0.232 & $0.003^{\mathrm{a}}$ & 0.863 \\
$1-5$ & 0.087 & 0.273 & 0.402 \\
$1-6$ & 0.223 & $0.018^{\mathrm{a}}$ & 0.940 \\
$1-7$ & 0.085 & 0.089 & 0.638 \\
$1-8$ & 0.311 & $0.040^{\mathrm{a}}$ & 0.831 \\
$1-9$ & 0.081 & 0.310 & 0.338 \\
$2-1$ & 0.095 & $0.012^{\mathrm{a}}$ & 0.648 \\
$2-2$ & 0.160 & $0.039^{\mathrm{a}}$ & 0.626 \\
$2-3$ & 0.107 & 0.320 & 0.443 \\
$3-1$ & 0.065 & 0.185 & 0.485 \\
$3-2$ & 0.119 & 0.050 & 0.754 \\
$3-3$ & 0.126 & $0.017^{\mathrm{a}}$ & 0.799 \\
$3-4$ & 0.062 & $0.034^{\mathrm{a}}$ & 0.670 \\
$3-5$ & 0.214 & $0.002^{\mathrm{a}}$ & 0.872 \\
\hline
\end{tabular}

${ }^{\mathrm{a}}$ Sample with linear regression between $\mathrm{Zr} / \mathrm{Ti}$ fluorescence ratio and lamination thickness at the $95 \%$ confidence interval or greater. 


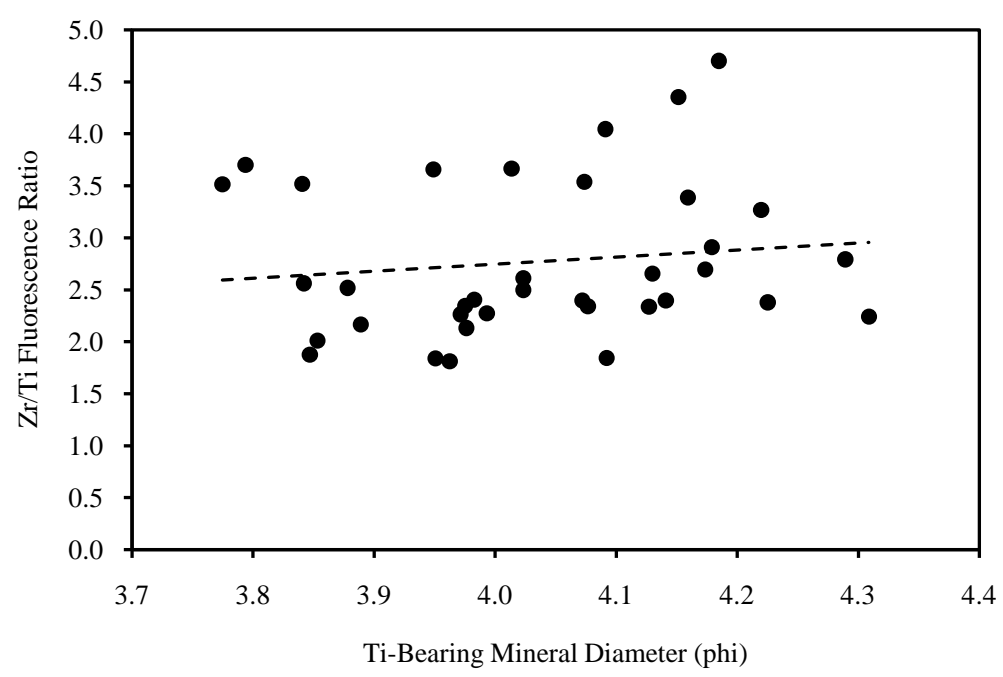

Figure 4. $\mathrm{Zr}$ /Ti fluorescence ratio with respect to Ti-rich mineral grain size (phi) $\left(R^{2}=0.016\right.$; $p$ for the regressed slope 0.489).

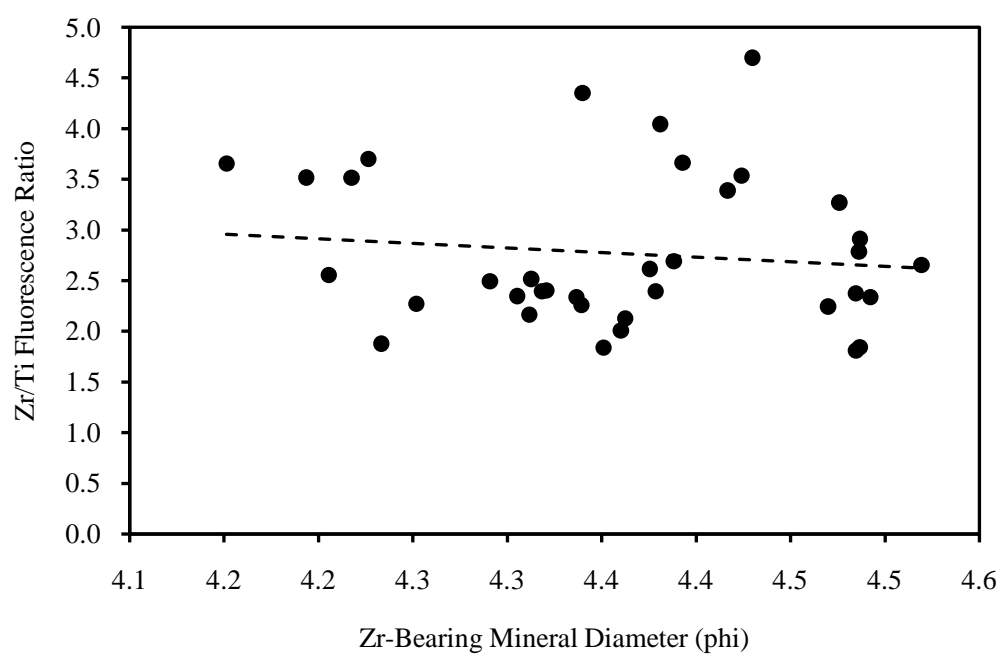

Figure 5. Zr/Ti fluorescence ratio with respect to Zr-rich mineral grain size (phi) $\left(R^{2}=0.014 ; p\right.$ for the regressed slope $\left.=0.472\right)$.

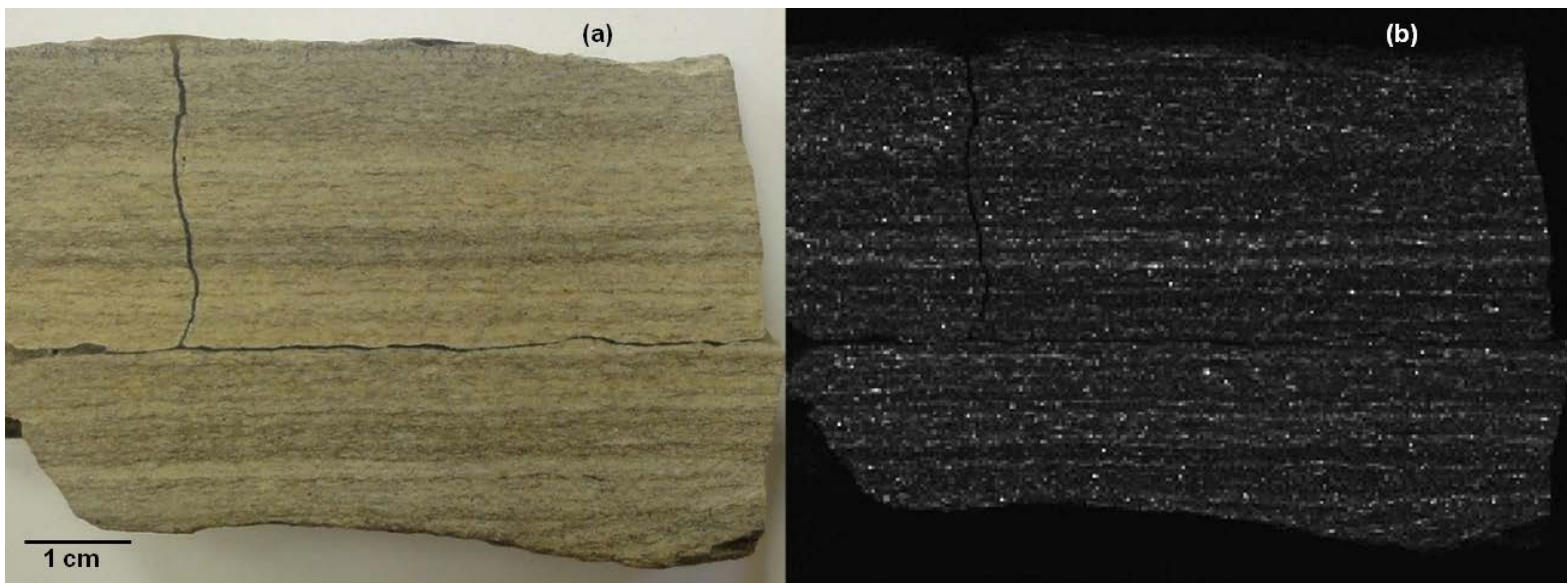

Figure 6. Fe-rich bands occur along black laminae. (a) MBC 1-5 rock sample. (b) Fe-fluorescence of MBC 1-5 rock sample. 

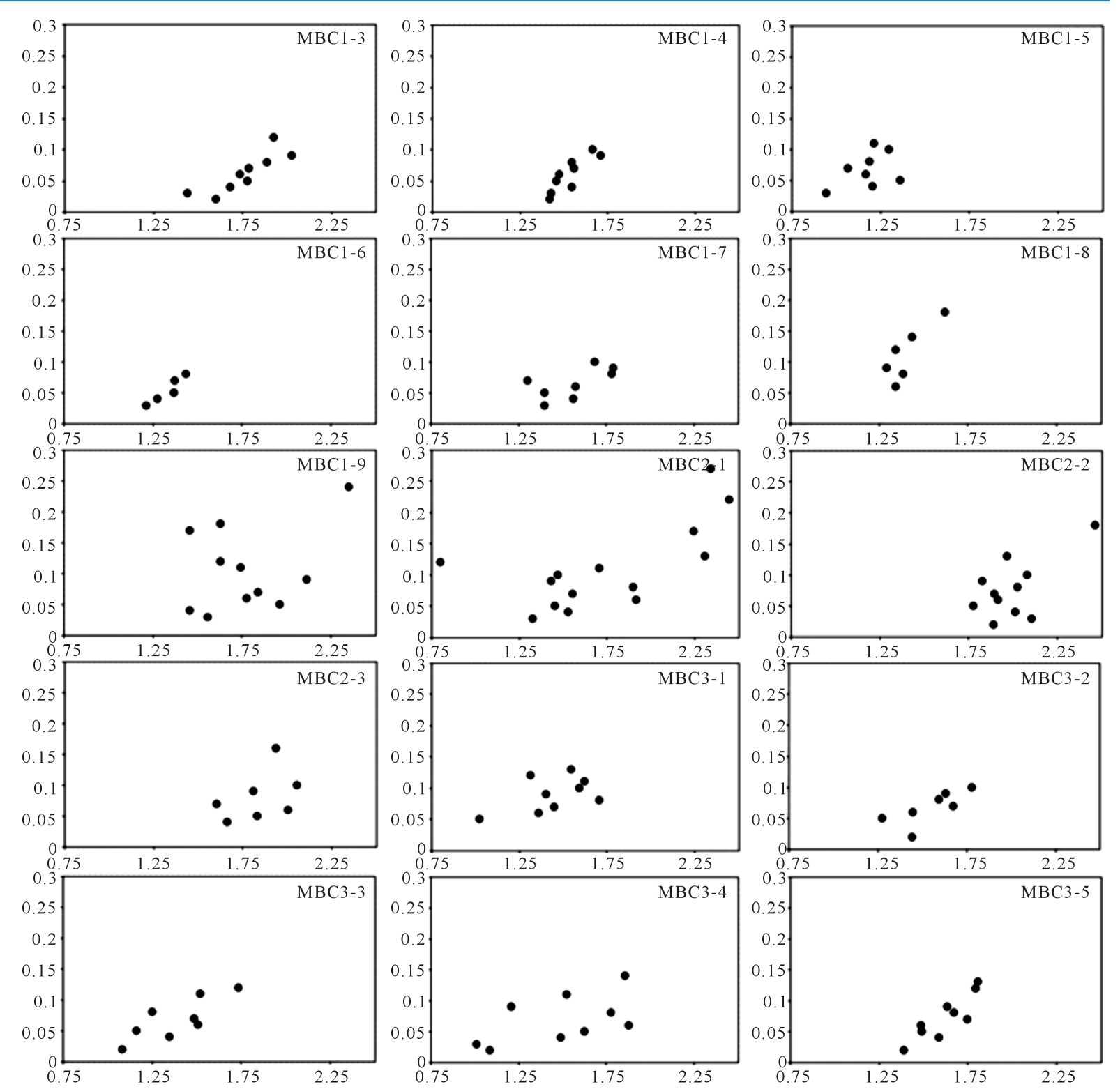

Figure 7. Correlation plots of lamination thickness in centimeter (y-axis) and $\mathrm{Zr} / \mathrm{Ti}$ fluorescence ratio (x-axis). All samples have positive correlation.

of fifteen samples had significant linear relationships between lamination thickness and $\mathrm{Zr} / \mathrm{Ti}$ ratio $(p<0.05$; Table 1). The remaining samples showed no significant relationship at the $95 \%$ confidence level; no negative correlations were observed.

Results from this research found that 1 ) both zircon and rutilated quartz grains were well-sorted and normally distributed, 2) rutilated quartz grain sizes were systematically correlated with zircon grain sizes, 3) neither zircon grain nor rutilated quartz grain size correlated with $\mathrm{Zr} / \mathrm{Ti}$ ratio, and 4) lamination thickness and $\mathrm{Zr} / \mathrm{Ti}$ fluorescence ratio had positive correlations.

\section{Analysis and Discussion}

\subsection{Previously Proposed Models for Sources of Zr/Ti Ratio Variation}

Geochemical properties have long been used to reconstruct histories of eolian sediments [9] [17]-[22]. The chemical composition of detrital sediments is mainly controlled by the mineralogy of the source rocks, the wea- 
thering regime, and the reactivity of the weathering products during transport [23]. In a study of late-Holocene sediments of Gormire Lake, UK, cyclical peaks of lithogenic elements ( $\mathrm{Si}, \mathrm{Ti}, \mathrm{K}, \mathrm{Rb}, \mathrm{Sr}, \mathrm{Zr}$ ) covaried with peaks in $\mathrm{Zr}$ /Ti ratio [24]. These results were interpreted as episodes of enhanced eolian input due to erosion following deforestation. Reference [25] studied hydrological changes in the Chihuahua Desert, Mexico and interpreted that the supply of Ti-bearing minerals associated with periods of summer precipitation and the abundance of Zr-bearing minerals reflected periods of eolian input. $\mathrm{Zr} / \mathrm{Ti}$ ratio was successfully used as a proxy for eolian intensity [11]-[13]. Similar interpretations were found in a study of changes in tropical African climate by reference [26]. Peaks in $\mathrm{Zr}$ /Ti ratio were interpreted as abrupt shifts to windy conditions. A combination of inorganic geochemical composition and varve thickness was used as a proxy for interpreting the depositional history of the northeastern Arabian Sea, Pakistan [27]. Increased lamination thickness and elevated $\mathrm{Zr} / \mathrm{Al}$ and Ti/Al ratios were interpreted as evidence for increased eolian event size. Similar interpretations of a relationship between eolian activity and varve thickness and detrital flux were drawn in other studies [28] [29]. All of these studies proposed similar models in which high $\mathrm{Zr} / \mathrm{Ti}$ ratio and lamination thickness are associated with periods of intense eolian activity.

In a study of volcanically derived dust in the deep sea, reference [9] proposed a model relating volcanic dust particle size to distance from source. The predicted traveled distance before deposition varied with particle size and height of the eruptive cloud. Fine particles from high eruptive clouds tended to travel the furthest. Reference [20] used grain sizes, elemental ratios, total organic content, and degree of bioturbation as proxies for interpreting depositional sequences and system tracts of black shales and limestones of the Oatka Creek Formation in the Devonian Appalachian Basin. Al was commonly found in clay minerals and was used as a proxy for fine-grained sediments. Si, Zr, and Ti were related to coarser sediments. Thus, high $\mathrm{Si} / \mathrm{Al}, \mathrm{Zr} / \mathrm{Al}$ and Ti/Al ratios reflected sand-sized sediment input. A decrease in any of these elemental ratios was associated with deposition in distal and basinal environments. In this model, heavy elements were size sorted along the travel path [10]. $\mathrm{Zr}$ was enriched in silt to fine sand and Ti was associated with clay [24]. In other words, high $\mathrm{Zr} / \mathrm{Ti}$ ratio was related to coarsening sediment input. Thus, a combination of high $\mathrm{Zr} / \mathrm{Ti}$ ratio and coarse-grained particles indicated sedimentation in relatively proximal depositional environments.

In summary, $\mathrm{Zr}$ and $\mathrm{Ti}$ abundances are used in essential proxies for analyzing eolian deposits because they are chemically immobile [30] [31]. There are two different proposed models to explain fluctuations in $\mathrm{Zr} / \mathrm{Ti}$ ratio: 1) high $\mathrm{Zr} / \mathrm{Ti}$ ratio and lamination thickness are associated with periods of intense eolian activity or 2) a combination of high $\mathrm{Zr} / \mathrm{Ti}$ ratio and coarse-grained particles indicate sedimentation in relatively proximal depositional environments. This research is using in situ geochemical compositions to identify potential driving mechanisms for variations in $\mathrm{Zr} / \mathrm{Ti}$ fluorescence ratio and lamination thickness.

\subsection{Sources of Zr/Ti Ratio Variation of the Brushy Canyon Formation Siltstones}

A particle's susceptibility to movement is strongly influenced by its size and shape as well as the packing and sorting of the surrounding sediment, and initial grain entrainment results from fluid drag and lift forces on more exposed grains [32]. In a series of wind-tunnel experiments of dry loose sand-sized sediments of a range of grain sizes, as wind velocity was slowly increased, less exposed grains were moved by fluid drag force [32]. When particle to fluid density ratio is low, the initial particle motion occurs at low fluid velocity [33]. Thus, denser and smaller grains have lower susceptibility to initial movement and require a relatively higher critical shear velocity to initiate motion due to their lesser exposed surface area and higher particle to fluid density ratio.

Since zircon particles are smaller and denser than rutilated quartz particles (Figure 3), zircon grains have lower susceptibility to particle movement. Variations in $\mathrm{Zr} / \mathrm{Ti}$ ratio are not correlated to grain size of either mineral (Figure 4 and Figure 5). These observations suggest that changes in $\mathrm{Zr} / \mathrm{Ti}$ ratio did not result from variations in mineral grain sizes but were likely from variations in mineral abundance. Consequently, high $\mathrm{Zr} / \mathrm{Ti}$ ratios were from increases in zircon abundance likely related to periods of enhanced erosion where fluid speeds were high enough to move particles with lower susceptibility to movement. In contrast, thicker laminations were associated with higher $\mathrm{Zr} / \mathrm{Ti}$ ratios (Figure 7); this is consistent with results from references [27]-[29]. Therefore, variations in $\mathrm{Zr} / \mathrm{Ti}$ ratio are most likely derived from fluctuations in erosional event intensity.

\subsection{Interpretation of Event Size}

In every rock sample, Ti-rich mineral particle size is coarser than that of Zr-rich mineral (Figure 3). Zr/Ti ratios 
are not correlated to grain size of either mineral (Figure 4 and Figure 5). The combination of these evidences suggests that changes in $\mathrm{Zr} / \mathrm{Ti}$ ratio did not result from sorting along the transport path or from varying distances of transportation. Changes in $\mathrm{Zr} / \mathrm{Ti}$ ratio are, therefore, most likely derived from fluctuations in eolian intensity. Wind erosion occurs mostly by particle collisions, and particle's susceptibility to movement is highly influenced by grain size and sorting [32]. Since zircon particles are smaller and denser than rutilated quartz particles, zircon has lower particle surface area. Zircon grains have lower susceptibility to particle movement. Consequently, high $\mathrm{Zr} / \mathrm{Ti}$ ratios likely imply periods of strong wind.

Shear velocity at the time of initial movement can be estimated by Rouse number

$$
R o=\frac{w_{s}}{\kappa u_{*}} .
$$

Here, $w_{s}$ is particle settling velocity, $\kappa$ is the von Karman constant (0.4), and $u_{*}$ is the shear velocity. The settling velocity of particle is determined by balancing the particle's gravitational force with its drag force, assuming that the drag coefficient, $C_{D}$, of a spherical particle in turbulent flow equals 0.4 - 0.5 [34]

$$
w_{s}=2\left(\sqrt{\frac{\rho_{s} g d_{s} C_{D}}{3 \rho}}\right) .
$$

In order to have these rutilated quartz and zircon travel in suspended load (Rouse number $<1$ ), shear velocity has to be higher than $10 \mathrm{~km} \cdot \mathrm{hr}^{-1}$. The wind speed at a given height $z$ above the surface is characterized by the Prandtl-von Karman equation

$$
u_{z}=\frac{u_{*}}{\kappa} \ln \left(\frac{z}{z_{o}}\right) .
$$

Here, $u_{z}$ is the wind speed at a given height $z$ and $z_{o}$ is the aerodynamic roughness length, which is approximately $1-3 \mathrm{~cm}$ for eolian megaripples [35]. The average wind velocity (at $10 \mathrm{~m}$ above ground, which is the international standard height for meteorological wind measurement [36]) is at least $150 \mathrm{~km} \cdot \mathrm{hr}^{-1}$, which is equivalent to a Category 1 hurricane. Reference [4] inferred that the parallel laminated siltstones in Delaware Mountain Group were deposited during seasonal storms. During the Permian, the Delaware basin was located in the trade-wind belt of the northern hemisphere [3]. Compositions of detrital feldspar suggested that the source areas were the Rockies and other uplifts [8]. Fine sand, silt, and clay were transported as wind-blown dust [7] by strong trade-wind periods [3].

\section{Conclusion}

In situ geochemical compositions measured by $\mu \mathrm{XRF}$ were used to identify driving mechanisms for variations in $\mathrm{Zr} / \mathrm{Ti}$. The results from this investigation showed that 1) both zircon and rutilated quartz grains were well-sorted and had log-normally distributed sizes, 2) rutilated quartz grain sizes were systematically correlated with zircon grain sizes, 3) neither zircon grain nor rutilated quartz grain size correlated with $\mathrm{Zr} / \mathrm{Ti}$ ratio, and 4) lamination thickness and $\mathrm{Zr} / \mathrm{Ti}$ fluorescence ratio were positively correlated. Therefore, fluctuations in $\mathrm{Zr} / \mathrm{Ti}$ likely resulted from changes in event sizes. A high $\mathrm{Zr} / \mathrm{Ti}$ fluorescence ratio indicates a period enhanced wind velocity and erosion at the source rather than shorter transport distance. The thinly laminated siltstones were deposited following erosion and transported by strong trade-winds or seasonal storms having estimated velocities of at least 150 $\mathrm{km} \cdot \mathrm{hr}^{-1}$, which was equivalent to a Category 1 hurricane. The methodology introduced here could be applied to stratigraphic correlation in similar siltstone units or to sedimentary units having a high windblown component. Different strata sections having similar patterns of $\mathrm{Zr} / \mathrm{Ti}$ fluorescence ratio could be derived from the same event and, therefore, correlated.

\section{Acknowledgements}

This project was funded a grant to M.M.T. from the donors of the American Chemical Society Petroleum Research Fund. The open access publishing fees for this article have been covered in part by the Texas A\&M University Online Access to Knowledge (OAK) Fund, supported by the University Libraries and the Office of the Vice President for Research. 


\section{References}

[1] Harms, J.C. (1974) Brushy Canyon Formation, Texas: A Deep-Water Density Current Deposit. Geological Society of America Bulletin, 85, 1763-1784. http://dx.doi.org/10.1130/0016-7606(1974)85<1763:BCFTAD>2.0.CO;2

[2] Harms, J.C. and Williamson, C.R. (1988) Deep-Water Density Current Deposits of Delaware Mountain Group (Permian), Delaware Basin, Texas and New Mexico. AAPG Bulletin, 72, 299-317.

[3] Fischer, A.G. and Sarnthein, M. (1988) Airborne Silts and Dune-Derived Sands in the Permian of the Delaware Basin. Journal of Sedimentary Research, 58, 637-643.

[4] Williamson, C.R. (1980) Sedimentology of Guadalupian Deep-Water Clastic Facies, Delaware Basin, New Mexico and West Texas. Trans-Pecos Region: New Mexico Geological Society, 31st Field Geological Guidebook, 195-204.

[5] Silver, B.A. and Todd, R.G. (1969) Permian Cyclic Strata, Northern Midland and Delaware Basins, West Texas and Southeastern New Mexico. AAPG Bulletin, 53, 2223-2251.

[6] Beaubouef, R.T., Rossen, C., Zelt, F.B., Sullivan, M.D., Mohrig, D.C. and Jennette, D.C. (1999) Deep-Water Sandstones, Brushy Canyon Formation, West Texas. AAPG Hedberg Field Research Conference, Texas, 15-20 April 1999, $48 \mathrm{p}$.

[7] Adams, J.E. (1936) Oil Pool of Open Reservoir Type. AAPG Bulletin, 20, 780-796.

[8] Hull, J.P.D. (1957) Petrogenesis of Permian Delaware Mountain Sandstone, Texas and New Mexico. AAPG Bulletin, 41, 278-307.

[9] Shaw, D.M., Watkins, N.D. and Huang, T.C. (1974) Atmospherically Transported Volcanic Glass in Deep-Sea Sediments: Theoretical Considerations. Journal of Geophysical Research, 79, 3087-3094. http://dx.doi.org/10.1029/JC079i021p03087

[10] Reynolds, R.L., Mordecai, J.S., Rosenbaum, J.G., Ketterer, M.E., Walsh, M.K. and Moser, K.A. (2010) Compositional Changes in Sediments of Subalpine Lakes, Uinta Mountains (Utah): Evidence for the Effects of Human Activity on Atmospheric Dust Inputs. Journal of Paleolimnology, 44, 161-175. http://dx.doi.org/10.1007/s10933-009-9394-8

[11] Ding, Z.L., Sun, J.M., Yang, S.L. and Liu, T.S. (2001) Geochemistry of the Pliocene Red Clay Formation in the Chinese Loess Plateau and Implications for Its Origin, Source Provenance and Paleoclimate Change. Geochimica et Cosmochimica Acta, 65, 901-913. http://dx.doi.org/10.1016/S0016-7037(00)00571-8

[12] Yang, S., Ding, F. and Ding, Z. (2006) Pleistocene Chemical Weathering History of Asian Arid and Semi-Arid Regions Recorded in Loess Deposits of China and Tajikistan. Geochimica et Cosmochimica Acta, 70, 1695-1709. http://dx.doi.org/10.1016/j.gca.2005.12.012

[13] Zech, M., Zech, R., Zech, W., Glaser, B., Brodowski, S. and Amelung, W. (2008) Characterization and Palaeoclimate of Loess-Like Permafrost Palaeosol Sequence in NE Siberia. Geoderma, 143, 281-295. http://dx.doi.org/10.1016/j.geoderma.2007.11.012

[14] FitzGerald, S. (2005) Micro-Spectroscopy-Shedding Light on Rock Formation. Spectroscopy Europe, 17, 24-25.

[15] Riley, N.A. (1941) Projection Sphericity. Journal of Sedimentary Research, 11, 94-95.

[16] Gunderson, S. (2011) Early Channel Evolution in the Middle Permian Brushy Canyon Formation, West Texas, USA. Master Thesis, Texas A\&M University, College Station.

[17] Glaccum, R.A. and Prospero, J.M. (1980) Saharan Aerosols over the Tropical North Atlantic-Mineralogy. Marine Geology, 37, 295-321. http://dx.doi.org/10.1016/j.geoderma.2007.11.012

[18] Jaenicke, R. and Schütz, L. (1978) Comprehensive Study of Physical and Chemical Properties of the Surface Aerosols in the Cape Verde Islands Region. Journal of Geophysical Research: Oceans, 83, 3585-3599. http://dx.doi.org/10.1029/JC083iC07p03585

[19] Schnetger, B., Brumsack, H.J., Schale, H., Hinrichs, J. and Dittert, L. (2000) Geochemical Characteristics of Deep-Sea Sediments from the Arabian Sea: A High-Resolution Study. Deep Sea Research Part II: Topical Studies in Oceanography, 47, 2735-2768. http://dx.doi.org/10.1016/S0967-0645(00)00047-3

[20] Ver Straeten, C.A., Brett, C.E. and Sageman, B.B. (2011) Mudrock Sequence Stratigraphy: A Multi-Proxy (Sedimentological, Paleobiological and Geochemical) Approach, Devonian Appalachian Basin. Palaeogeography, Palaeoclimatology, Palaeoecology, 304, 54-73. http://dx.doi.org/10.1016/j.palaeo.2010.10.010

[21] Goldberg, K. and Humayun, M. (2010) The Applicability of the Chemical Index of Alteration as a Paleoclimatic Indicator: An Example from the Permian of the Parana Basin, Brazil. Palaeogeography, Palaeoclimatology, Palaeoecology, 293, 175-183. http://dx.doi.org/10.1016/j.palaeo.2010.05.015

[22] Schatz, A.K., Scholten, T. and Kuhn, P. (2015) Paleoclimate and Weathering of the Tokaj (Hungary) Loess-Paleosol Sequence. Palaeogeography, Palaeoclimatology, Palaeoecology, 426, 170-182.

http://dx.doi.org/10.1016/j.palaeo.2015.03.016 
[23] Mackenzie, F.T. (2005) Sediments, Diagenesis, and Sedimentary Rocks: Treatise on Geochemistry. 7th Edition, Elsevier Science, Amsterdam.

[24] Oldfield, F., Wake, R., Boyle, J., Jones, R., Nolan, S., Gibbs, Z., et al. (2003) The Late-Holocene History of Gormire Lake (NE England) and Its Catchment: A Multiproxy Reconstruction of Past Human Impact. The Holocene, 13, 677690. http://dx.doi.org/10.1191/0959683603hl654rp

[25] Roy, P.D., Rivero-Navarette, A., Lopez-Balbiaux, N., Pérez-Cruz, L.L., Metcalfe, S.E., Sankar, G.M., et al. (2013) A Record of Holocene Summer-Season Palaeohydrological Changes from the Southern Margin of Chihuahua Desert (Mexico) and Possible Forcings. The Holocene, 23, 1105-1114. http://dx.doi.org/10.1177/0959683613483619

[26] Brown, E.T., Johnson, T.C., Scholz, C.A., Cohen, A.S. and King, J.W. (2007) Abrupt Change in Tropical African Climate Linked to the Bipolar Seesaw over the Past 55,000 Years. Geophysical Research Letters, 34, L20702. http://dx.doi.org/10.1029/2007GL031240

[27] Lückge, A., Doose-Rolinski, H., Khan, A.A., Schulz, H. and von Rad, U. (2001) Monsoonal Variability in the Northeastern Arabian Sea during the Past 5000 Years: Geochemical Evidence from Laminated Sediments. Palaeogeography, Palaeoclimatology, Palaeoecology, 167, 273-286. http://dx.doi.org/10.1016/S0031-0182(00)00241-8

[28] Dean, W.E., Forester, R.M. and Bradbury, J.P. (2002) Early Holocene Change in Atmospheric Circulation in the Northern Great Plains: An Upstream View of the 8.2 Ka Cold Event. Quaternary Science Reviews, 21, 1763-1775. http://dx.doi.org/10.1016/S0277-3791(02)00002-1

[29] Hu, F., Slawinski, D., Wright, H., Ito, E., Johnson, R., Kelts, K., et al. (1999) Abrupt Changes in North American Climate during Early Holocene Times. Nature, 400, 437-440. http://dx.doi.org/10.1038/22728

[30] Muhs, D.R. and Benedict, J.B. (2006) Eolian Additions to Late Quaternary Alpine Soils, Indian Peaks Wilderness Area, Colorado Front Range. Arctic, Antarctic, and Alpine Research, 38, 120-130. http://dx.doi.org/10.1657/1523-0430(2006)038[0120:EATLQA]2.0.CO;2

[31] Reynolds, R., Belnap, J., Reheis, M., Lamothe, P. and Luiszer, F. (2001) Aeolian Dust in Colorado Plateau Soils: Nutrient Inputs and Recent Change in Source. Proceedings of the National Academy of Sciences of the United States of America, 98, 7123-7127. http://dx.doi.org/10.1073/pnas.121094298

[32] Nickling, W. (1988) The Initiation of Particle Movement by Wind. Sedimentology, 35, 499-511. http://dx.doi.org/10.1111/j.1365-3091.1988.tb01000.x

[33] Iversen, J.D., Greeley, R., Marshall, J.R. and Pollack, J.B. (1987) Aeolian Saltation Threshold: The Effect of Density Ratio. Sedimentology, 34, 699-706. http://dx.doi.org/10.1111/j.1365-3091.1987.tb00795.x

[34] Morsi, S.A. and Alexander, A.J. (1972) An Investigation of Particle Trajectories in Two-Phase Flow Systems. Journal of Fluid Mechanics, 55, 193-208. http://dx.doi.org/10.1017/S0022112072001806

[35] Zimbelman, J., Scheidt, S., de Silva, S., Bridges, N. and Spagnuolo, M. (2014) Roughness Height Measurements for Megaripples in the Puna of Argentina, form Flow over the Largest Megaripples, and Implications for Mars. 45th Lunar and Planetary Institute Science Conference, Woodlands, 17-24 March 2014, 1359.

[36] Bailey, B., McDonald, S., Bernadett, D. and Markus, M. (1997) Wind Resource Assessment Handbook. AWS Scientific Inc., Albany. 